\title{
The Didactic Narrator in C.S. Lewis's The Lion, the Witch and the Wardrobe
}

\author{
Glen Mynott
}

\begin{abstract}
And now we come to one of the nastiest things in this story. Up to that moment Edmund had been feeling sick, and sulky, and annoyed with Lucy for being right, but he hadn't made up his mind what to do. When Peter suddenly asked him the question he decided all at once to do the meanest and most spiteful thing he could think of. He decided to let Lucy down.

(Lewis 1972, p.44)
\end{abstract}

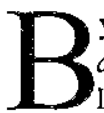
$y$ the time he came to write The Lion, the Witch and the Wardrobe, during the late 1940s, C.S. Lewis already had a reputation as a writer of theological texts. During the war Lewis made three series of broadcasts on Christian themes that were later published as Broadcast Talks (1942), Christian Behaviour (1943), and Beyond Personality (1944). These were followed in 1947 by what many commentators consider his most carefully considered and judiciously written theological work, Miracles. Taking this context as a starting point, ] want to argue that The Lion, the Witch and the Wardrobe operates on an extratextual level as a lesson in "Christian behaviour' for young children, and that Lewis provides his readers with a wise adult narrator who guides them through the story, in the way that the adult characters in the story guide Peter. Susan, Edmund and Lucy through their adventures.

In particular, I am concerned with the way that Lewis creates, at different levels of his text authoritative narrators who tell their child readers and audience how to respond in particular situations. and attempt to direct them to the distinction between right and wrong, good and evil. Lewis's narrators can be viewed as teachers who take it upon themselves to instruct their child audience in Christian behaviour and respect for their elders. By telling the readers how to react, they create, as John Stephens has suggested. 'a dominating narration' which constructs 'a model for exerting control over readers at a narrative level deeper than that of the implied reader'. Stephens explains that 'the forms of direct address and the use of overworded registers which often characterize omniscient narration can exert this [ideological] control over the reader quite directly, by assuming that certain objectives and outcomes of the story are commonsensically natural and desirable' (Stephens 1992. p.22).

\section{Social context}

The didactic narrative of Lewis's text may well have seemed a bit 'old fashioned' when The Lion, the Witch and the Wardrobe was published in 1950. However, considering the social and political context in which the book was written, it is not entirely surprising that a latemiddle aged Christian man of conservative leanings should write such a book in the 1940s.

It has been shown (Bane 2000) that The Lion, the Witch and the Wardrobe, and perhaps the other Narnia tales, originated from a series of stories that Lewis told to the evacuee convent schoolgirls that he and his long term partner, Janie Moore, took in during the early years of the war, between 1940 and 1942 (Wilson 1990, p. 186). Bane points out that the short fragment that survives from one of these stories is almost identical to the opening passages of The Lion, the Witch and the Wardrobe. Although there is some doubt about when the book was written, it is generally accepted that it was not completed until 1948 or 1949, when it was read to Roger Lancelyn Green (Wilson 1990, p.220)

The turbulence of the war years and the social and political changes that came about immediately after the war might well have been seen by Lewis as threatening the ordered, conservative and Christian world that is presented in his writing. The post-war years brought a Labour government that embarked on a large-scale programme of social reform: nationalisation, the establishment of the National Health Service, free and compulsory secondary education for all, state pensions and benefits. The social reforms were accompanied by a programme of economic austerity that included the continuation of wartime rationing and increased taxation. In addition, social changes, such as the increase in the number of women going out to work and the decline in the deference of the "working class' for their 'social superiors', led to the creation of a very different England from the one that had existed before the war.

These changes were not to everyone's satisfaction, and Lewis expressed his displeasure by referring to the Chancellor of the Exchequer, Sir Stafford Cripps, as the nursery governess of England' (Wilson 1990, p.215). 
Lewis's brother Warnie complained in a diary entry for November 1947 that:

Potatoes are put 'on rations' on a scale of $3 \mathrm{lbs}$ per week for the bourgeois. And so the last 'filler' food disappears from the diet, and the days of real hunger come upon us. It's extraordinary how one is conditioned by a secure past: even now I can't grasp the fact that I, WHL, will go to bed hungry and get up hungry; these, I say, are things that happen to nations one reads about in the papers; not to me.

(W.H. Lewis 1982, pp.215-6).

Also. shortly before his death in November 1963, Lewis expressed his dismay at the prospect of a new Labour government:

My brother tells me gloomily that it is an absolute certainty that we shall have a Labour Government within a few months, with all the regimentation, austerity and meddling which they so enjoy.... if they get in with a big majority, it will take ten vears to break it down - which means that both of us have in all probability seen our last Conservative government.

(quoted in Wilson 1990, p.297).

Lewis's response to this change was to recreate in the Narnia stories a nostalgic version of his own childhood in which the distinctions between good and bad were clear cut, and in which everyone, including children know their place and show deference to their social superiors. In order to instruct his child readers in correct behaviour and Christian morality, Lewis creates in his stories a series of male narrators, working at different levels, as teachers. to present his vision of how things should be.

Levels of narration within The Lion, the Witch and the Wardrobe

In The Lion, the Witch and the Wardrobe, didactic narrators appear at different levels. The main narrator, or storyteller, operates at an extratextual level, addressing his readers directly in order to instruct them. Within the story, there are three further male adult/authority figures who provide advice and guidance to Peter, Susan, Edmund and Lucy and, indirectly, to the readers. The children in the story. with the exception of Edmund, set the example for readers by following the advice they are given. Edmund, who is presented as a naughty, self-willed boy. does not follow advice, and as a result, he is led into mortal danger and saved from death only by Aslan's ultimate sacrifice. The lesson is that danger and discomfort await those children who stray from the 'truth' and refuse to accept the wise advice of their elders.

\section{The intrusive adult,'male' narrator}

The main narrator has all the attributes of the professional storyteller who wins the confidence of his audience through his informal, if patronising style. He immediately presents himself as the guide, the omniscient authority figure who will lead his child readers through the events of the story, explaining what he believes needs to be explained along the way. The story begins in a conventional fairy-tale manner in which the main characters and the setting are introduced:

Once there were four children whose names were Peter, Susan, Edmund and Lucy. This story is about something that happened to them when they were sent away from London during the war because of the air-raids. They were sent to the house of an old Professor who lived in the heart of the country, ten miles from the nearest railway station and two miles from the nearest post office. He had no wife and he lived in a very large house with a housekeeper called Mrs Macready and three servants. (Their names were Ivy, Margaret and Betty, but they do not come into the story much.) He himself was a very old man with shaggy white hair which grew over most of his face as well as on his head, and they liked him almost at once.

(Lewis 1972, p.9)

Already, expectations of a forthcoming adventure are aroused; readers share the children's sense of the 'strange' and await the mysteries that lie within the house. In this opening paragraph, the narrator has already appealed to the sympathies of his readers, presenting himself as a friend, prepared to share a secret with them by, for instance, introducing three irrelevant characters and telling the children, in an aside, that these people will not play a significant part in the story. Such devices are designed to win the confidence of the child reader. Here is an adult 
who is prepared to talk to the children as a friend, and help them to understand the story by sharing his omniscience with them. However, what is also happening here is the establishment of the teacher-pupil relationship, with the narrator presenting himself as the all-knowing adult to whom the children must look for the answers to all questions.

Throughout the text, the narrator juxtaposes an informal conversational approach with clear didactic messages which are aimed at the moral and Christian development of his child audience. At the beginning of the book, one piece of advice is given to the reader three times, and Lucy, with whom it is associated, is presented as a sensible person for having followed it. When Lucy enters the wardrobe for the first time, we are told that she leaves the door open 'because she knew that it is very foolish to shut oneself into any wardrobe' (Lewis 1972, p. 12). This is repeated a few paragraphs later when we are told that she has 'left the door open, for she knew that it is a very silly thing to shut oneself into a wardrobe' (Lewis 1972 , p.13). When she makes her second visit to Narnia, we are told once again that she does not shut the door properly 'because she knew that it is very silly to shut oneself into a wardrobe, even if it is not a magic one' (Lewis 1972 , p.30). However, when Edmund follows her 'he jumped in and shut the door, forgetting what a very foolish thing this is to do' (Lewis 1972, p.30). Edmund has already been shown as spiteful and unpleasant and, of course, he is the child who doesn't follow 'good advice'. This is an example of his reckless rebelliousness and his failure to listen to his elders.

The danger into which Edmund is led and from which Aslan has to rescue him is the result of his failure to act on the advice of adults. Later, when all four children go into the wardrobe to hide from Mrs Macready, Peter, like Lucy, a very 'sensible' child does not close the door 'for, of course, he remembered, as every sensible person does, that you should never shut yourself up in a wardrobe' (Lewis 1972, p.52). Throughout, a clear distinction is made between those who follow advice, such as Peter and Lucy, and those who do not, such as Ednuund. As the narrator has already told us that Edmund is unpleasant and untruthful, this division comes to represent the binary opposites of 'good' and 'bad'. Edmund's 'badness' is presumably his failure to conform to the narrator's moral code for child behaviour. This leads to a hyperbolic denouncement of Edmund's behaviour:

And now we come to one of the nastiest things in this story. Up to that moment Edmund had been feeling sick, and sulky, and annoyed with Lucy for being right, but he hadn't made up his mind what to do. When Peter suddenlyasked him the question he decided all at once to do the meanest and most spiteful thing he could think of. He decided to let Lucy down.

'Tell us, Ed,' said Susan.

And Edmund gave a very superior look as if he were far older than Lucy (there was really only a year's difference) and then a little snigger and said, 'Oh, yes, Lucy and I have been playing pretending that all her story about a country in the wardrobe is true. Just for fun, of course. There's nothing there really.'

Poor Lucy gave Edmund one look and rushed out of the room.

Edmund, who was becoming a nastier person every minute, thought that he had scored a great success, and went on at once to say, 'There she goes again.'

(Lewis 1972, pp.44-5)

The effect of this episode is that Edmund is marginalized by the other children who, although they do not believe Lucy's story, express their disapproval of Edmund's taunting of her. The narrator is quite prominent in this passage; he does not just relate events, but tells readers how to respond to them. He interprets Edmund's motives, and portrays him in a particularly 'bad' light: he did 'one of the nastiest things in the story'; 'he decided all at once to do the meanest and most spiteful thing he could think of'; he 'gave a very superior look ... and then a little snigger'; 'Edmund ... was becoming a nastier person every minute'.

Edmund's unpleasantness is re-emphasised later in the story when he arrives at the Witch's castle and realizes that the lion in the courtyard is only a statue: 
And he stood there gloating over the stone lion, and presently he did something very silly and childish. He took a stump of lead pencil out of his pocket and scribbled a moustache on the lion's upper lip and then a pair of spectacles on its eyes. The he said, "Yah! Silly old Aslan! How do you like being a stone? You thought yourself mighty fine, didn't you?

(Lewis 1972, p.89)

Later, it appears that the narrator has a clearly defined understanding of what is suitable for young children to read. The followers of the Witch, as one might expect in a narrative where the binary divisions are so clear-cut, are hideous and ugly, too hideous even to be described to little children. By referring to the restrictions imposed on him by adults, the narrator cleverly reinforces his relationship with the child reader by presenting himself as one of them, someone who would tell them more if he were permitted:

But such people! Ogres with monstrous teeth, and wolves, and bull-headed men; spirits of evil trees and poisonous plants; and other creatures whom I won' $t$ describe because if I did the grownups would probably not let you read this bookCruels and Hags and Incubuses, Wraiths, Horrors, Efreets, Sprites, Orknies, Wooses, and Ettins.

(Lewis 1972, p.138)

There are no limits to the narrator's intrusion into the story to offer advice. Sometimes this advice is on quite trivial matters such as what food is good to eat:

... all the children thought - and I agree with them-that there's nothing to beat goodfreshwater fish if you eat it when it has been alive half an hour ago and has come out of the pan half a minute ago.

(Lewis 1972, pp.70-1)

As Lynne Vallone discusses in more detail in her contribution to this volume, Edmund does not enjoy the meal as his appetite has been corrupted by 'bad magic food' (Lewis 1972, p.82).

The narrator even intervenes to comment on the grammar of his characters and instructs his readers:
'It's all right,' [Mr Beaver] was shouting. 'Come out, Mrs Beaver. Come out, Sons and Daughters of Adam. It's all right! It isn't Her!' This was bad grammar of course, but that is how beavers talk when they are excited; I mean in Narnia - in our world they usually don't talk at all.

(Lewis 1972, pp.97-8)

At some points, the narrator interrupts his story with a digression that is designed to draw his readers into the narrative by comparing them with the children in the story, suggesting that all 'good' children undergo similar spiritual experiences. For instance, when Mr Beaver mentions Aslan we are told that:

A very curious thing happened. None of the children knew who Aslan was any more than you do; but the moment the Beaver had spoken these words everyone felt quite different. Perhaps it has sometimes happened to you in a dream that someone says something which you don't understand but in the dream it feels as if it had some enormous meaning - either a terrifying one which turns the whole dream into a nightmare or else a lovely meaning too lovely to put into words, which makes the dream so beautiful that you remember it all your life and are always wishing you could get into that dream again. It was like that now. At the name of Aslan each one of the children felt something jump in its inside. Edmund felt a sensation of mysterious horror. Peter felt suddenly brave and adventurous. Susan felt as if some delicious smell or some delightful strain of music had just floated by her. And Lucy got the feeling you have when you wake up in the morning and realize that it is the beginning of the holidays or the beginning of summer.

(Lewis 1972, p.65)

The effect of this spiritual event is effectively to present the children with a vision of their own inner selves. A similar effect is produced when Susan and Lucy ride on Aslan's back. Their experience is transferred to the reader, through the narrator's comparison with riding a horse:

That ride was perhaps the most wonderful thing that happened to them in Narnia. Have you ever had a gallop on a horse? Think of that; and then take away the heavy noise of the hoofs and the 
jingle of the bits and imagine instead the almost noiselesspadding of the great paws. Then imagine instead of the black or grey or chestnut back of the horse the soft roughness of golden fur, and the mane flying back in the wind. And then imagine you are going about twice as fast as the fastest racehorse. (Lewis 1972, p.149-50)

What we see in this passage is a journey through the Garden of Eden, the Utopia that awaits all true Christians. It is implied that this is what awaits those children who follow the Christian example. The narrator's attempt to describe the feeling of sensation the children experience when riding on Aslan's back, by comparing it with riding a horse, tells us a great deal about the intended readership of this book; especially in 1950s Britain, the children who would have been familiar with horse or pony riding w'would almost certainly have belonged to the middle or upper classes.

Susan and Lucy's grief following Aslan's sacrifice is similarly transferred to the reader:

Ihope no one who reads this book has been quite as miserable as Susan and Lucy were that night; but if you have been - if you've been up all night and cried till you have no more tears left in youyou will know that there comes in the end a sort of quietness. Youfeel as if nothing was ever going to happen again.

(Lewis 1972, pp.143-4)

Unlike many of the best-known children's books - from those of George MacDonald and Lewis Carroll to J.K. Rowling and Philip Pullman - in Lewis's narrative it is always the adults who know best. When children question their judgement, it is the adult who is proved right. When $\mathrm{Mr}$ Beaver and the children heard the jingling bells of what they thought was the Witch's sledge 'Mr Beaver was out of the cave like a flash':

Perhaps you think, as Lucy thought for a moment, that this was a very silly thing to do? But it was really a very sensible one. He knew he could scramble to the top of the bank among bushes and brambles without being seen; and he wanted above all things to see which way the Witch's sledge went.

(Lewis 1972, p.97)
The second level of narrative

The expectation that children will listen to and follow the wise advice of their elders is also apparent at a second level of narration. At various points in the story the Professor, $\mathrm{Mr}$ Beaver and Aslan each takes on the role of omniscient narrator, sharing their all-knowing wisdom with the four children and seeking to guide them through their difficulties. Given the time and context in which the Chronicles began, it should come as no surprise that all Lewis's didactic narrators are male.

\section{The Professor}

When Peter and Susan are concerned about Lucy's insistence that she had been to a magic country on the other side of the wardrobe, they decide to seek the advice of the Professor. The Professor applies logic to their problems and proposes that there are only three possibilities for their sister's behaviour:

'Either your sister is lelling lies, or she is mad, or she is telling the truth. You know she doesn't tell lies and it is obvious that she is not mad. For the moment then and unless any further evidence turns up, we must assume that she is telling the truth.'

(Lewis 1972, p.47)

However, the children require more direct advice, and eventually Susan asks the pertinent question:

\section{'But what are we to do?' said Susan. She felt that the conversation was beginning to get off the point.}

'Mydearyoung lady, ' said the Professor, suddenly looking up with a very sharp expression at both of them, 'there is one plan which no one has yet suggested and which is well worth trying.'

'What's that?' said Susan.

'We might all try minding our own business, ' said he. And that was the end of the conversation.

(Lewis 1972, pp.49-50)

Impressed by the Professor's logic and his relaxed attitude to Lucy's behaviour, the children follow his advice and leave Lucy alone. 


\section{Mr Beaver}

The first adult that the children meet when they visit Narnia together is Mr Beaver, and he tells them about Mr Tumnus's arrest and takes over the responsibility for their guidance. Mr Beaver feeds the children, tells them about the situation in Narnia, and about Aslan. He plays the role of the messenger whose task it is to bring the children to Aslan. When it is discovered that Edmund has gone missing, Mr Beaver acts quickly to protect the children and his family:

'What on earth are we to do, Mr Beaver?' said Peter.

'Do?' said Mr Beaver, who was already putting on his snow-boots, 'do? We must be off at once. We haven't a moment to spare!'

'We'd better divide into four search parties, 'said Peter, 'and all go in different directions. Whoever finds him must come back here at once and -'

'Search parties, Son of Adam?' said Mr Beaver; 'what for?'

'Why, to look for Edmund, of course!'

'There's no point in looking for him,' said Mr Beaver.

'What do you mean?' said Susan. 'He can't be far away' yet. And we've got to find him. What do you mean when you say there's no use looking for him?'

'The reason there's no use looking,' said $\mathrm{Mr}$ Beaver, 'is that we know already where he's gone!' Everyone stared in amazement. 'Don't you understand?' said Mr Beaver. 'He's gone to her, to the White Witch. He has betrayed us all.'

'Oh, surely - oh, really!' said Susan, 'he can't have done that.'

'Can't he?' said Mr Beaver, looking very hard at the three children, and everything they' wanted to say died on their lips, for each felt suddenly quite certain inside that this was exactly what Edmund had done.

(Lewis 1972, p.79)
The rhetorical style of this passage creates a learning experience through which, by a series of questions and answers, the children work out for themselves the truth about their brother. It is Mr Beaver who guides the children away from the house and leads them by a safe route to Aslan.

\section{Aslan}

From the moment that the three children are introduced to Aslan they feel hopeful of rescuing their brother. Aslan's leadership is inspiring and they never question his authority: "All shall be done," said Aslan. "But it may be harder than you think" (Lewis 1972, p.118). Aslan, like the narrator, talks to children as if they were friends and shares with them his knowledge of the future: "Come, Son of Adam, and I will show you a far-off sight of the castle where you are to be king" (Lewis 1972, p.118). Aslan directs the children in the battle against the White Witch and establishes them in their new kingdom, before departing. Indeed, he teaches the children how to be brave, wise and just, and leaves only, when as kings and queens (adults), they have learned everything he has to teach and are ready to pass on his lessons to others.

The effects of Lewis's narrative style

All the narrators in The Lion, the Witch and the Wardrobe take on the role of teaching young children how to behave, establishing simple binary oppositions, such as 'right' and 'wrong', 'good' and 'bad', and providing them with lessons in Christian morality. Just as the children in the story are guided by the Professor, Aslan and $\mathrm{Mr}$ Beaver, the readers are guided by the intrusive narrator/storyteller who intervenes frequently to direct the way the reader responds to the story. Thus, the reader is confronted with didactic messages, working at different levels within the text. Authority is portrayed as omniscient, and just as the male narrator controls the text, so the male adult figure is seen as the rightful guide or leader in a society that is based on Christian values. Lewis's response to the social change of the post-war years is to draw on a nostalgic past in which the old values of deference to male authority, obedience and honour remain at the forefront, and a place in a Christian paradise remains the objective of all 'good' people. 


\section{REFERENCES}

\section{Primary texts}

Lewis, C. S. (1942) Broadcast Talks. London, Geoffrey Bles.

Lewis, C. S. (1943) Christian Behaviour. London, Geoffrey Bles.

Lewis, C. S. (1944) Beyond Personality. London, Geoffrey Bles.

Lewis, C. S. (1947) Miracles: A Preliminary Study. London, Geoffrey Bles.

Lewis, C. S. (1972) The Lion, the Witch \& the Wardrobe. Harmondsworth. Penguin (originally published 1950)

\section{Secondary texts}

Bane. Mark 'Myth made truth: the origins of the Chronicles of Narnia', available from World Wide Web: http:/www.tayloru.edu/upland/ programs/lewis/articles/bane.html (visited 3 December 2001)

Lewis, W. H. (1982) Brothers and Friends: The Diaries of Major Warren Hamilton Lewis ed. by Clyde S. Kilby \& Margery Lamp Mead. San Francisco \& London, Harper \& Row.

Stephens. John (1992) Language and Ideology in Children's Fiction. London \& New York, Longman.

Wilson, A. N. (1990) C. S. Lewis: A Biography. London. Collins.
BIOGRAPHICAL NOTE

Dr. Glen Mynott researches in the areas of Renaissance literature, and Children's Literature and Librarianship. He has written papers on Elizabethan drama, the Harry Potter books, British war stories for children, and the use of Information and Computing Technology (ICT) in supporting children's reading and learning. Glen is currently one of three editors of The New Review of Children's Literature and Librarianship. $\mathrm{He}$ is also a student on a PGCE course at the University of Warwick, training to be a secondary teacher of English and Drama, and a part-time tutor on the Distance learning mode of the MA in Children's Literature programme at the University of Surrey Roehampton.

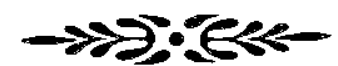

